\title{
Fine needle aspiration cytology of head and neck lesions and its correlation with histopathology
}

\author{
Pathak R ${ }^{1}$, Prasad KBR ${ }^{1}$, Rauniyar $\mathrm{SK}^{1}$, Pudasaini $\mathrm{S}^{1}$, Pande $\mathrm{K}^{1}$, Koirala $\mathrm{S}^{1}$, Kafle \\ $\mathrm{S}^{1}$, Jha $\mathrm{A}^{2}$, Chalise $\mathrm{S}^{2}$, Basnyat $\mathrm{AS}^{2}$ \\ ${ }^{\prime}$ Department of Pathology, Nepal Medical College Teaching Hospital, Jorpati, Kathmandu, Nepal \\ ${ }^{2}$ Department of Pathology, Bhaktapur Cancer Hospital, Bhaktapur, Nepal
}

\author{
Keywords: \\ Fine needle aspiration \\ cytology; \\ Histopathology; \\ Lymph node; \\ Thyroid; \\ Salivary gland; \\ Soft tissues
}

\begin{abstract}
Background: Fine needle aspiration cytology is a minimally invasive technique used in the initial diagnosis of different types of lesions located in head and neck region commonly originating from cervical lymph node, thyroid gland, salivary glands and soft tissues. The objective of this study was to evaluate the diagnostic accuracy, sensitivity and specificity of FNAC in various head and neck lesions in correlation with their histopathological examination.
\end{abstract}

Materials and methods: A hospital based prospective study was conducted among 209 patients with palpable head and neck region swellings in the Department of Pathology, Bhaktapur Cancer Hospital and the Department of Pathology, Nepal Medical College from August 2014 to July 2015. FNAC were done from palpable masses of head and neck regions. Data entry and analysis were done using SPSS 17.

Result: There were 209 FNAC cases enrolled, out of which lymph node lesions ( $n=128$ ) were the most common lesions followed by thyroid $(n=40)$, other soft tissues $(n=27)$ and salivary gland $(n=14)$. Reactive lymph nodes, colloid goiter, epidermoid cyst and sialadenosis were the predominant diagnosis of lymph nodes, thyroid gland, soft tissues and salivary gland respectively. Highest accuracy, sensitivity and specificity were observed in thyroid gland, salivary gland and soft tissues. However, four false negative results for malignancy were reported in lymph node lesions.

Conclusion: Head and neck region swellings are the commonly encountered conditions. FNAC being highly accurate, sensitive and specific makes it useful and reliable procedure for screening and diagnosis of palpable masses in head and neck region.

\section{INTRODUCTION}

Fine Needle Aspiration Cytology (FNAC) is a simple, quick and inexpensive diagnostic technique with minimal trauma and high specificity. ${ }^{1,2}$ Being a minimally invasive

\section{Correspondence:}

Dr Rakesh Pathak, MBBS, MD

Lecturer, Department of Pathology,

Nepal Medical College Teaching Hospital, Jorpati, Kathmandu, Nepal

Email:dr_rakesh@hotmail.com technique, it is particularly suitable in sensitive area where incision biopsy is difficult and it avoids need of surgery if the lesions show non- neoplastic, suspected metastatic or recurrent tumor. ${ }^{3}$ The modern method of FNAC was introduced by Martin and Ellis in 1930 and now it has become a popular procedure in the evaluation of various palpable lumps. $^{4}$

FNAC is applicable to palpable lesions of head and neck 
Table 1: Distribution of Head and Neck Lesions

\begin{tabular}{|c|c|c|c|c|c|}
\hline \multirow{2}{*}{ Tissue } & \multicolumn{2}{|c|}{ Bhaktapur Cancer Hospital } & \multicolumn{2}{|c|}{ Nepal Medical College } & \multirow{2}{*}{ Total } \\
\hline & Male & Female & Male & Female & \\
\hline Lymph nodes & 52 & 28 & 30 & 18 & $128(61.2 \%)$ \\
\hline Thyroid gland & 10 & 18 & 4 & 8 & $40(19.2 \%)$ \\
\hline Salivary glands & 7 & 2 & 4 & 1 & $14(6.7 \%)$ \\
\hline Other soft tissues & 7 & 15 & 2 & 3 & $27(12.9 \%)$ \\
\hline Total & 76 & 63 & 40 & 30 & $209(100 \%)$ \\
\hline
\end{tabular}

Table 2: Cytology and Histopathological co-relation of Lymph nodes

\begin{tabular}{|c|c|c|c|c|c|c|}
\hline FNAC diagnosis & $\begin{array}{l}\text { No. of } \\
\text { cases }\end{array}$ & $\begin{array}{c}\text { No. of } \\
\text { cases with } \\
\text { Surgical } \\
\text { biopsy }\end{array}$ & $\begin{array}{l}\text { Diagnosis consistent } \\
\text { with Cytology }\end{array}$ & $\begin{array}{c}\text { Diagnosis } \\
\text { inconsistent with } \\
\text { Cytology }\end{array}$ & $\begin{array}{l}\text { Histopathological } \\
\text { Diagnosis }\end{array}$ & Accuracy \\
\hline Reactive lymph node & 43 & 16 & 7 & 9 & $\begin{array}{c}\text { Reactive=7, GL=5, } \\
\text { NHL=2(FN), HL=2(FN) }\end{array}$ & $43.8 \%$ \\
\hline $\begin{array}{l}\text { Granulomatous } \\
\text { lymphadenitis (GL) }\end{array}$ & 28 & 13 & 10 & 3 & $\begin{array}{c}\mathrm{GL}=10, \text { Kikuchi fujimoto } \\
\text { disease }=3\end{array}$ & $76.9 \%$ \\
\hline $\begin{array}{l}\text { Metastatic squamous } \\
\text { cell carcinoma }\end{array}$ & 15 & 5 & 5 & - & $\begin{array}{l}\text { Metastatic squamous cell } \\
\text { carcinoma }=5\end{array}$ & $100 \%$ \\
\hline $\begin{array}{l}\text { Metastatic } \\
\text { adenocarcinoma }\end{array}$ & 5 & 2 & 2 & - & $\begin{array}{c}\text { Metastatic } \\
\text { adenocarcinoma }=2\end{array}$ & $100 \%$ \\
\hline $\begin{array}{l}\text { Metastatic Small cell } \\
\text { carcinoma }\end{array}$ & 5 & 4 & 1 & 3 & $\begin{array}{c}\text { Metastatic small cell } \\
\text { carcinoma }=1, \quad \text { NHL }=3\end{array}$ & $25 \%$ \\
\hline $\begin{array}{l}\text { Metastatic poorly } \\
\text { differentiated } \\
\text { adenocarcinoma }\end{array}$ & 5 & 3 & 1 & 2 & $\begin{array}{c}\text { Metastatic poorly } \\
\text { differentiated } \\
\text { carcinoma }=1, \mathrm{NHL}=2\end{array}$ & $33.3 \%$ \\
\hline $\begin{array}{l}\text { Metastatic } \\
\text { nasopharyngeal } \\
\text { carcinoma }\end{array}$ & 1 & 1 & 1 & - & $\begin{array}{l}\text { Metastatic nasopharyngeal } \\
\text { carcinoma }=1\end{array}$ & $100 \%$ \\
\hline $\begin{array}{l}\text { Metastatic } \\
\text { dysgerminoma }\end{array}$ & 1 & - & - & - & - & - \\
\hline $\begin{array}{l}\text { Non Hodgkins's } \\
\text { Lymphoma (NHL) }\end{array}$ & 14 & 14 & 11 & 3 & $\begin{array}{c}\text { NHL }=11 \\
\text { Metastatic } \\
\text { adenocarcinoma }=1 \\
\text { Metastatic small cell } \\
\text { carcinoma }=2\end{array}$ & $78.5 \%$ \\
\hline $\begin{array}{l}\text { Hodgkin's Lymphoma } \\
\text { (HL) }\end{array}$ & 3 & 3 & 3 & - & $\mathrm{HL}=3$ & $100 \%$ \\
\hline Abscess & 8 & 5 & 3 & 2 & Abscess $=3$, & $60 \%$ \\
\hline Total & 128 & 66 & 44 & 22 & & \\
\hline
\end{tabular}

region including various neoplastic and non-neoplastic lesions of lymph node, salivary gland, thyroid gland and other soft tissues. ${ }^{5}$ An early diagnosis and differentiation of such lesions from inflammatory to neoplastic play crucial role on planned treatment. ${ }^{6}$ The prime objective of the study was to assess the utility of FNAC in diagnosis of head and neck lesions and correlate the cyto-morphological features with histo-pathological findings.

\section{MATERIAL AND METHODS}

The present study comprised of 209 cases of palpable head and neck masses, 139 cases were from Bhaktapur Cancer Hospital $(\mathrm{BCH})$ and 70 cases from Nepal Medical College (NMC). Ethical clearance was obtained from institutional review committee. The patients had undergone preoperative FNAC and subsequently histopathological examinations (HPE) were performed in the Department of Pathology, $\mathrm{BCH}$ and the Department of Pathology, NMC from August 2014 to July 2015. All patients were asked about history related to head and neck swelling, probable etiological cause, family history of tuberculosis and other relevant disease. Informed consent from each individual was taken. Patients with non-diagnostic type of FNAC and previous history of chemotherapy, radiation therapy or any antituberculosis drugs were excluded from the study.

FNAC was performed by $22-23$ gauze needle with $10 \mathrm{ml}$ syringe. The aspirated material was smeared on minimum 2 clean glass slides, wet fixed or air dried followed by 
Table 3: Cytology and Histopathological co-relation of Thyroid Gland

\begin{tabular}{lcccccc}
\hline \multicolumn{1}{c}{ FNAC diagnosis } & $\begin{array}{c}\text { No. of } \\
\text { cases }\end{array}$ & $\begin{array}{c}\text { No. of } \\
\text { cases with } \\
\text { Surgical } \\
\text { biopsy }\end{array}$ & $\begin{array}{c}\text { Diagnosis consistent } \\
\text { with Cytology }\end{array}$ & $\begin{array}{c}\text { Diagnosis } \\
\text { inconsistent with } \\
\text { Cytology }\end{array}$ & $\begin{array}{c}\text { Histopathological } \\
\text { Diagnosis }\end{array}$ \\
\hline Colloid goiter & 18 & 4 & 4 & - & Colloid goiter=4 & $100 \%$ \\
\hline Hyperplastic nodule & 3 & 2 & 2 & - & Hyperplastic nodule=2 & $100 \%$ \\
\hline Hashimoto thyroiditis & 7 & - & - & - & - & - \\
\hline Dequervain thyroiditis & 4 & - & - & - & Papillary carcinoma $=4$ & - \\
\hline Papillary carcinoma & 4 & 4 & 4 & - & - & - \\
\hline Anaplastic carcinoma & 1 & - & - & - & Hurthle cell neoplasm=1 & $100 \%$ \\
\hline Hurthle cell neoplasm & 2 & 1 & 1 & - & - \\
\hline Follicular neoplasm & 1 & - & - & - & - \\
\hline Total & 40 & 11 & 11 & & - \\
\hline
\end{tabular}

Table 4: Cytology and Histopathological co-relation of Salivary Gland

\begin{tabular}{|c|c|c|c|c|c|c|}
\hline FNAC diagnosis & $\begin{array}{l}\text { No. of } \\
\text { cases }\end{array}$ & $\begin{array}{c}\text { No. of } \\
\text { cases with } \\
\text { Surgical } \\
\text { biopsy } \\
\end{array}$ & $\begin{array}{l}\text { Diagnosis consistent } \\
\text { with Cytology }\end{array}$ & $\begin{array}{c}\text { Diagnosis } \\
\text { inconsistent with } \\
\text { Cytology }\end{array}$ & $\begin{array}{l}\text { Histopathological } \\
\text { Diagnosis }\end{array}$ & Accuracy \\
\hline Sialadenosis & 6 & 2 & 2 & - & Sialadenosis $=2$ & $100 \%$ \\
\hline Sialadenitis & 4 & 1 & 1 & - & Sialadenitis $=1$ & $100 \%$ \\
\hline Acinic cell carcinoma & 2 & 1 & 1 & - & Acinic cell carcinoma $=1$ & $100 \%$ \\
\hline $\begin{array}{l}\text { Mucoepidermoid } \\
\text { carcinoma }\end{array}$ & 2 & 2 & 2 & - & $\begin{array}{l}\text { Mucoepidermoid } \\
\text { carcinoma }=2\end{array}$ & $100 \%$ \\
\hline Total & 14 & 6 & 6 & - & & \\
\hline
\end{tabular}

Table 5: Cytology and Histopathological co-relation of other soft tissues

\begin{tabular}{lcccccc}
\hline FNAC diagnosis & $\begin{array}{c}\text { No. of } \\
\text { cases }\end{array}$ & $\begin{array}{c}\text { No. of } \\
\text { cases with } \\
\text { Surgical } \\
\text { biopsy }\end{array}$ & $\begin{array}{c}\text { Diagnosis consistent } \\
\text { with Cytology }\end{array}$ & $\begin{array}{c}\text { Diagnosis } \\
\text { inconsistent with } \\
\text { Cytology }\end{array}$ & $\begin{array}{c}\text { Histopathological } \\
\text { Diagnosis }\end{array}$ \\
\hline Epidermal Cyst & 15 & 12 & 12 & - & Epidermal cyst $=12$ & $100 \%$ \\
\hline Lipoma & 5 & 4 & 4 & - & Lipoma $=4$ & $100 \%$ \\
\hline Hemangioma & 4 & 3 & 3 & - & Hemangioma $=3$ & $100 \%$ \\
\hline Schwannoma & 1 & 1 & - & - & Schwannoma $=1$ & - \\
\hline Cysticercosis & 2 & - & - & - & & - \\
\hline Total & 27 & 20 & 20 & & & \\
\hline
\end{tabular}

staining with Giemsa and Papanicolaou (PAP). Similarly, biopsies obtained from those patients were fixed in $10 \%$ formalin and processed. Different sections so obtained were stained with Hematoxylin and Eosin (HE) stain. Finally stained sections were observed under microscope and cyto- histopathological correlation was made. Data were processed and analyzed using SPSS version 17.

\section{RESULTS}

The present study included 209 cases of head and neck lesions ranged from 1 to 82 years of age in which $55.5 \%$ were male and $44.5 \%$ were female. Maximum incidence was observed below 50 years 127 (61\%) cases and remaining 82 $(39 \%)$ cases were above 50 years.

Among the head and neck lesions FNAC presented at $\mathrm{BCH}$ and NMC, lymph nodes showed the highest incidence followed by thyroid gland, soft tissues and salivary glands. Male predominance was seen in lymph nodes $(64 \%)$ and salivary gland $(79 \%)$ whereas in thyroid gland $(65 \%)$ and soft tissues (67\%) female predominance was observed (Table 1).

Out of 128 FNAC cases of lymph node lesions, 66 samples were available for HPE and the final diagnosis after 
HPE were reactive lymphadenitis $(n=7)$, granulomatous lymphadenitis $(\mathrm{n}=17)$, metastatic squamous cell carcinoma $\mathrm{n}=(5)$, metastatic adenocarcinoma $(\mathrm{n}=3)$, metastatic small cell carcinoma $(n=3)$, metastatic poorly differentiated carcinoma $(\mathrm{n}=1)$, metastatic nasopharyngeal carcinoma $(\mathrm{n}=1)$, Hodgkin's Lymphoma $(\mathrm{n}=5)$, Non-Hodgkin's Lymphoma $(n=18)$, Kikuchi fujimoto disease $(n=3)$ and abscess ( $n=3$ ) with different accuracy rates (Table 2). Four false negative cases for malignancy were also observed among reactive lymph nodes.

Among 40 FNAC cases of thyroid gland, only 11 samples were available for HPE and the final diagnosis observed were colloid goiter $(n=4)$, hyperplastic nodule $(n=2)$, papillary carcinoma $(\mathrm{n}=4)$ and hurthle cell neoplasm $(\mathrm{n}=1)$ with $100 \%$ accuracy rate (Table 3 ).

Similarly, 6 salivary gland samples were available for HPE and the final diagnosis observed were sialadenosis $(\mathrm{n}=2)$, sialadenitis $(\mathrm{n}=1)$, acinic cell carcinoma $(\mathrm{n}=1)$ and mucoepidermoid carcinoma $(\mathrm{n}=2)$ with accuracy rate of $100 \%$ (Table 4).

Among 27 FNAC cases of soft tissues, 20 samples were obtained for HPE and the final diagnosis after HPE were epidermal cyst $(n=12)$, lipoma $(n=4)$, hemangioma $(n=3)$ and schwannoma $(\mathrm{n}=1)$ with $100 \%$ accuracy rate (Table 5 ).

\section{DISCUSSION}

Head and neck lesions are the commonly encountered clinical conditions. In this study the most common sites for the occurrence of head and neck masses were lymph nodes followed by thyroid, other soft tissues and salivary gland. Our findings were comparable to other studies that have shown lymph nodes as the most frequent site for FNAC in head and neck region. ${ }^{7,8}$

Among 128 cases lymph node lesions, reactive lymphadenitis was the most common pathological finding followed by metastatic carcinomas, granulomatous lymphadenitis, lymphomas and abscess. Other studies observed reactive lymphadenitis as the most common diagnosis of lymph node similar to our study. ${ }^{9-11}$ In contrast, few studies showed tubercular lymphadenitis was the most frequent finding among lymph nodes. ${ }^{1,2,5-7}$ Out of 66 cases were available for HPE, NHL (27.3\%) was the commonest pathological findings followed by granulomatous lymphadenitis (25.8\%), metastatic carcinoma (19.7\%), reactive lymphadenitis (10.6\%), HL (7.6\%), Kikuchi fujimoto disease (4.5\%) and abscess $(4.5 \%)$. Four false negative cases for malignancies at lymph nodes were reported from FNAC which were later confirmed by histo-pathological examination.

Out of 40 thyroid FNAC cases only 11 cases were obtained for HPE correlation. These thyroid lesions revealed colloid goiter (36\%) and papillary carcinoma (36\%) as the predominant finding followed by hyperplastic nodule and hurthle cell neoplasm. Rathod et al and Rajbhandari et al observed similar findings with maximum incidence of colloid goiter and then papillary carcinoma. ${ }^{69}$ A study by Singal et al reported colloid goiter as the most commonly observed disorder in thyroid region similar to our finding. ${ }^{10}$ Rout et al. found colloid goiter as the most common among thyroid swelling followed by colloid goiter with cystic degeneration. ${ }^{12}$

Among 14 FNAC cases of salivary gland, only 6 were received for HPE correlation. Sialadenosis and sialadenitis together comprised 3 cases $(50 \%)$ whereas mucoepidermoid carcinoma accounted 2 cases $(33.3 \%)$ and 1 case $(16.7 \%)$ of acinic cell carcinoma were observed. Chronic sialadenitis is the most common non-neoplastic lesion observed in salivary gland followed by neoplastic pleomorphic adenoma. ${ }^{5,9,13}$ Other studies reported pleomorphic adenoma as the most common lesion found in salivary gland. 2,7,8,10,14,15. A study by Rathod et al found mucoepidermoid carcinoma as the commonest malignancy in salivary gland similar to our study. ${ }^{6}$

In this study we obtained 27 FNAC cases of soft tissues whereas 20 samples were available for HPE. We observed 12 $(60 \%)$ cases of epidermal cyst which was the most common soft tissue lesions followed by lipoma, hemangioma and schwannoma. Suryawanshi et al reported epidermal cyst comprised maximum benign lesions and then lipoma similar to our study. ${ }^{5}$ A study by Singal et al found the lipoma as the common soft tissues lesion followed by epidermal cyst and hemangioma which was not in accordance with our study. ${ }^{10}$

In this study we correlated the FNAC results with the HPE findings of available specimens. Four false negative for malignancy were reported initially by FNAC. Being blind sampling procedure, we might not get proper samples, samples with mixed macrophages and lymphoid tissues in the specimen might have created such misinterpretations which were later confirmed by HPE. However 44 (67\%) FNAC cases of lymph nodes were found consistent with HPE findings however, thyroid gland, salivary gland and other soft tissues showed $100 \%$ consistent with HPE.

\section{CONCLUSION}

FNAC is recommended as a safe, reliable, quick, inexpensive and minimally invasive technique in the diagnosis of head and neck lesions. It serves as a complementary diagnostic procedure to histopathological examination in the diagnosis and management of palpable head and neck lesions.

\section{ACKNOWLEDGEMENTS}

We sincerely thank all the surgeons, pathologists, histopathology technicians and the participants of Nepal Medical College, Jorpati and Bhaktapur Cancer Hospital, Bhaktapur, Nepal. 


\section{REFERENCES}

1. Mitra P, Bharti R, Pandey MK. Role of fine needle aspiration cytology in head and neck lesions of paediatric age group. J Clin Diagn Res 2013;7:1055-8. Crossref

2. Poorey VK, Tyagi A. Accuracy of fine needle aspiration cytology in head and neck masses.Indian J Otolarngol Head Neck Surg. 2014;66:182-6. Crossref

3. Langlois S, Chryssidis S, editors. Orell \& Sterrett's Fine needle aspiration cytology. 5th edition.Churchill Livingstone: 2012.pg41.

4. Martin H, Ellis EB. Biopsy of needle puncture and aspiration. Ann Surg. 1930;92:169-81. Crossref

5. Suryawanshi KH, Damle RP, Nikumbh DB, Dravid NV, Newadkar DV. Cyto-histopathological correlations of head and neck swellings in a rural hospital in north maharshtra: our experience. Ann Pathol Lab Med 2015;2:121-6.

6. Rathod GB, Parmar P. Fine needle aspiration cytology of swellings of head and neck region. Indian J Med Sci 2012;66:49-54. Crossref

7. Khetrapal S, Jetley S, Jairajpuri Z, Rana S, Kohli S. FNAC of head \& neck regions and its utility in clinical diagnosis: A study of 209 cases. Nat J. Med Res 2015;5:33-8.

8. Ishar T, Gupta RK, Khajuria A. Role of FNAC in diagnosis of nonthyroidal head and neck lesions. JK Science 2012;14:9-13.
9. Rajbhandari M, Dhakal P, Shrestha S, et al. The correlation between fine needle aspiration cytology and histopathology of head and neck lesions in Kathmandu University hospital. Kathmandu Univ Med J 2013;11:296-9. Crossref

10. Singal P, Bal MS, Kharbanda J, Sethi PS. Efficacy of fine needle aspiration cytology in head and neck lesions. Int J Med Dent Sci 2014;3:421-30. Crossref

11. Mainali N, Suwal RB. Patterns of lymphadenopathy on fine needle aspiration cytology in eastern Nepal. Journal of Pathology of Nepal 2015;5:814-6. Crossref

12. Rout K, Ray CS, Behera SK, Biswal R. A comparative study on thyroid swellings. J Otolaryngol Head Neck Surg 2011;63:370-2. Crossref

13. Gupta R, Dewan D, Kumar D, Suri J. Fine needle aspiration cytology (FNAC) of salivary gland lesions with histopathological correlation in a district hospital of Jammu region. Indian J Pathol Oncol 2016;3:32-7. Crossref

14. Gupta G, Joshi DS, Shah A, Ganshi M, Shah NR. FNAC of head and neck swellings. GCSMC J Med Sci 2014;3:38-41.

15. Sunil KY, Premi HS, Kishan P, et al. Role of fine needle aspiration cytology in salivary gland tumors in correlation with their histopathology: A two year prospective study. J Clin Diagn Res 2011;5:1375-80. 